\title{
THE TWOFOLD APPROACH TO CHILDREN'S FREEDOM OF MOVEMENT RIGHTS UNDER EUROPEAN LAW: CAN 'CHILDREN'S EQUILIBRIUM' GUIDE THE INTERPRETATION OF THE POST-BREXIT RIGHTS OF UK CHILDREN RESIDING IN THE EU?
}

\author{
Teodora Petrova*
}

\begin{abstract}
Summary: The United Kingdom's decision to leave the EU is causing a strong political, legal and, last but not least, social turmoil. Arguably, the impact is even greater for children who are growing up as part of the Union, and belong to families of mixed nationalities, and/or have cross-border relations to different states and educational systems. The interpretation of the post-Brexit EU law rights of children with British nationality should first examine the pre-Brexit children's rights under the European freedom of movement law to assess the exact scope of the change that the removal of European citizenship will entail.
\end{abstract}

An overview of the case law of the European Court of Justice ("ECJ") on the freedom of movement rights demonstrates an evolution in the understanding of the rights of children under EU law, a development which observes more and more children's specific needs, as embodied in children's fundamental rights provisions. This development came about in a sporadic fashion, shifting between treating children's rights as ancillary add-ons to their parents' EU law market rights and acknowledging children's individual rights. Eventually, the ECJ attempted to reinforce the latter approach by examining children's Union citizenship and rights under EU law by referencing children's fundamental rights, enshrined in Article 24 of the Charter of Fundamental Rights of the European Union, for the sake of maintaining "children's equilibrium".

The referring to the so-called “children's equilibrium"' would suggest that a respective child-related approach was adopted in the interpretation of European law via which the stated equilibrium could be achieved. Yet, apart from the inclusion of Article 24 in the legal discussion, the development of a comprehensive child-related approach with a view to the securing of children's equilibrium requires further judicial engagement in two main directions. Namely, the need for more guidance remains, especially along the lines of elaborating the EU's 
uniform children's rights obligations and making sure that children are seen as individual rights holders.

On the basis of these existing criteria, for the purpose of this paper a child-related approach is to indicate the consideration and integration of children's rights in the legal reasoning, by regarding children as independent rights-bearing individuals. The paper will argue that the upcoming legal uncertainties could be levelled down if the goal of maintaining children's equilibrium through the child-related approach was applied in the interpretation of the EU law-related rights of children with British nationality. Further, since the proposed approach could also be based on the Convention on the Rights of the Child, it could also serve as a bridge for the application of the "children's equilibrium" approach in the UK with a view to a time when the Charter is not to be applicable any longer.

\section{Introduction}

'The [European] Council has not defended the rights of its citizens, be they British or from the other EU27 countries. [...] You and the UK have negotiated away some of the most fundamental rights of over 4 million committed Europeans and at the end of the transition we will find ourselves in a far poorer position'. ${ }^{1}$ This harsh statement is part of a letter to the President of the European Council, Mr. Donald Tusk, by the campaign groups the3million and British in Europe, which are stated to represent approximately 4.6 million citizens affected by Brexit.

Undoubtedly, the United Kingdom's decision to leave the EU is causing strong political, legal and, last but not least, social turmoil. UK citizens living in the Member States and, conversely, European citizens residing in the UK, are currently in a state of legal limbo, which will affect their lives. On the one hand, the current state of the discussion on the withdrawal conditions poses the threat of a no-deal scenario, ${ }^{2}$ which could lead to numerous subsequent uncertainties, including those related to the residence rights of citizens. ${ }^{3}$ On the other, some of the proposed measures for the post-Brexit period, such as the UK's EU Settle-

\footnotetext{
${ }^{1}$ L O'Carroll, 'EU Leaders Accused of Not Protecting Citizens' Rights in Brexit Deal' The Guardian (21 March 2018, London) <https://www.theguardian.com/politics/2018/ mar/21/eu-leaders-accused-of-not-protecting-citizens-rights-in-brexit-deal> accessed 14 April 2018.

2 D Boffey, 'EU Assault on May's White Paper Heightens "No Deal" Brexit Fears' The Guardian (18 July 2018, London) <https://www.theguardian.com/politics/2018/jul/18/eu-assault-on-mays-white-paper-heightens-no-deal-brexit-fears> accessed 27 July 2018.

${ }_{3}^{3}$ 'EU Settlement Scheme: Statement of Intent. An Analysis by the3million' (The3million, 11 July 2018) 5 <https://www.the3million.org.uk/publications> accessed 27 July 2018.
} 
ment Scheme, prepared by the Home Office, demonstrate that the initial promises on the rights of EU citizens - in terms of the declaration that there will be no change for those who are already lawfully residing in the UK - will not be kept. ${ }^{4}$

Brexit-related confusion is unfolding against the background of the process of European integration, which has enabled EU citizens to build numerous and multifaceted ties with different Member States. Arguably, the impact is even greater for children who are growing up as part of the Union, and belong to families of mixed nationalities, and/or have cross-border relations to different states and educational systems. ${ }^{5}$ The Brexit consequences could turn out to be obstacles for children who have ties with several Member States and would like to maintain these. The interpretation of the post-Brexit EU law rights of children with British nationality should first examine pre-Brexit children's rights under the European freedom of movement law in order to assess the exact scope of the change that the removal of European citizenship will entail.

An overview of the case law of the European Court of Justice (ECJ) on the freedom of movement rights demonstrates an evolution in the understanding of the rights of children under EU law, a development which observes more and more children's specific needs, as embodied in children's fundamental rights provisions. This is not to say that the gradual development came about in a smooth and non-contradictory fashion. Quite the opposite, when children's rights were simply understood as ancillary add-ons to their parents' European 'economic, mobile citizenship $^{6}$ and/or related rights, the children's own rights were neglected in the discussion. Yet, if children were considered as autonomous holders of their own freedom of movement rights, their rights would be interpreted with consideration to their entitlement to care, ${ }^{7}$ the best interest prin-

\footnotetext{
${ }^{4}$ Some campaign groups have argued that there are several troubling main aspects of the proposed EU Settlement Scheme. A major concern is the requirement for the application for settlement status, which could lead to many not applying and not acquiring the status. Children appear to be a group at particular risk, since their registration is bound to be conditional on their parents or carers. In this regard, there have been arguments that systems for EU nationals 'must avoid an increase in children finding themselves undocumented as a result of practical barriers or policy decisions'. See 'Brexit and Children's Rights' (Coram) <www.childrenslegalcentre.com/promoting-childrens-rights/policy/brexit-childrens-rights/> accessed 19 August 2018.

5 'Brexit: Children's Rights at Risk or Future Opportunity in the Global Era?' (Coram, London 2017) 7.

${ }^{6}$ C O’Brien, 'I Trade, Therefore I Am: Legal Personhood in the European Union’ (2013) 50(6) Common Market Law Review 1647.

${ }^{7}$ For instance, in Case C-60/00 Mary Carpenter $v$ Secretary of State for the Home Department ECLI:EU:C:2002:434, children's entitlement to care was the anchoring element for the residence rights of their third-country national carer. The judgment is examined in greater
} 
ciple, ${ }^{8}$ and the diverse ties children can have with parents, carers, and different states. ${ }^{9}$

Eventually, the ECJ attempted to reinforce the latter approach by examining children's Union citizenship and rights under EU law by referencing children's fundamental rights ${ }^{10}$ as enshrined in Article 24 of the Charter of Fundamental Rights of the European Union. This approach, termed 'children's equilibrium', ${ }^{11}$ entails the elaboration of the dependency relationship between a child with Union citizenship and his or her third-country national parent with consideration to: the best interests of the child, the age of the child, the child's physical and emotional development, the extent of his or her emotional ties to both parents/carers, and the risks which a separation from the third-country national parent can pose for the child's wellbeing. The paying of greater attention to the multifaceted needs of children is welcomed in the light of the previous lack of discussion on the topic.

Reference to the so-called 'children's equilibrium' would suggest that a respective child-related approach was adopted in the interpretation of the European law through which the stated equilibrium could be achieved. Yet, apart from the inclusion of Article 24 in the legal discussion, the development of a comprehensive child-related approach with a view to securing children's equilibrium requires further judicial engagement in two main directions. Namely, as academic scholarship indicates, the need for more guidance remains, especially along the lines of elaborating the EU's uniform children's rights obligations ${ }^{12}$ and making sure that children are seen as individual rights holders. ${ }^{13}$

detail below in part 3.1 Children's entitlement to care and the right to family life.

${ }^{8}$ To exemplify, in Case C-244/06 Dynamic Medien Vertriebs GmbH $v$ Avides Media AG ECLI:EU:C:2008:85, the Court states that the best interest of the child trumps the free movement of goods, given that proper proportionality is executed.

9 For example, Case C-148/02 Garcia Avello v Belgian State ECLI:EU:C:2003:539; and Case C-353/06 Stefan Grunkin and Dorothee Regina Paul ECLI:EU:C:2008:559.

${ }^{10}$ Case C-133/15 HC Chavez-Vilchez and Others $v$ Raad van bestuur van de Sociale verzekeringsbank and Others ECLI:EU:C:2017:354, para 72.

11 Chavez-Vilchez (n 10) para 72; Case C-82/16 KA, MZ, MJ, NNN, OIO, RI, BA v Belgische Staat ECLI:EU:C:2018:308, para 72.

12 I refer to criticism of the ECJ's sporadic and uncomprehensive engagement with the issue of children's rights and the omission of discussion on the relation between their rights and social rights, stemming from European legal discourse. See O’Brien (n 6) 1644; H Stalford, 'The CRC in Litigation under EU Law' in Ton Liefaard and Jaap E Doek (eds), Litigating the Rights of the Child: The UN Convention on the Rights of the Child in Domestic and International Jurisprudence (Springer 2015) 229.

13 H Stalford, K Hollingsworth and S Gilmore, 'Introducing Children's Rights Judgments' in Helen Stalford, Kathryn Hollingsworth and Stephen Gilmore (eds), Rewriting Children's Rights Judgments: From Academic Vision to New Practice (Hart Publishing 2017) 5. 
On the basis of these existing criteria, for the purpose of the paper, a child-related approach is to indicate the integration and consideration of children's rights in the legal reasoning, by regarding children as independent rights-bearing individuals, rather than assigning them the role of 'passive object of concern'. ${ }^{14}$ Such an approach could be a starting point in guiding the interpretation of the EU law-related rights of children with British nationality residing in the EU. The current state of debates on Brexit demonstrates that there will be novelties which the legal systems will have to accommodate, like the fact that the UK's departure will not ensue the equalisation of British citizens with third-country nationals, as some of the pre-Brexit rights will be retained. ${ }^{15}$

The paper will argue that the upcoming legal uncertainties could be levelled out if the goal of maintaining children's equilibrium through the child-related approach is applied in the interpretation of the EU law-related rights of children with British nationality. Further, since the proposed approach could also be based on the Convention on the Rights of the Child, it could also serve as a bridge for the application of the "children's equilibrium' approach in the UK with a view to a time when the Charter is no longer to be applicable. ${ }^{16}$

The first part of the article will begin by laying out the parameters of the theoretical background behind the child-related approach and will introduce the EU primary law background on the nature of children's rights. The paper will continue by portraying how the ECJ has gradually moved closer to the incorporation of the child-related approach in its reasoning when interpreting freedom of movement law. The respective part will also discuss the inconsistencies in the reasoning of the Court in the related case law. The last part of the article will argue that the post-Brexit interpretation of the rights of children can pay regard to the lessons drawn from the freedom of movement case law and attempt to avoid the omissions in the consideration of children's own rights and interests. In this regard, the children's equilibrium concept can be backed up by a child-related approach aimed at underlining children's individual rights

\footnotetext{
14 ibid.

${ }^{15}$ For instance, the conditions for EU citizens of the right of residence under European law will apply for UK citizens residing within the Union. See Commission, 'Draft Agreement on the withdrawal of the United Kingdom of Great Britain and Northern Ireland from the European Union and the European Atomic Energy Community' (Position paper Commission to EU27) TF50 (2018) 35, art 12.

${ }^{16}$ Experts on the topic of children's rights protection in the UK state that one of the biggest concerns is that Brexit will lead to the removal of the children's rights guarantees stemming from the EU Charter. See Brexit and Children Coalition, 'Making Brexit Work for Children: The Impact of Brexit on Children and Young People' (The Children's Society, November 2017) 6 <www.childrenssociety.org.uk/what-we-do/resources-and-publications/makingbrexit-work-for-children> accessed 3 August 2018.
} 
for the development of reciprocal approaches for the protection of children's rights, especially in view of the legal uncertainties stemming from the unprecedented withdrawal of an EU Member State.

\section{The nature of children's rights}

Some authors have argued that one of the greatest concerns surrounding the legal deliberation of children's rights is the tendency for the interests of the child to become 'subsumed by' or to be overlooked in the deliberation of adults' interests. ${ }^{17}$ Hence, the establishment of an approach which could avoid the aforementioned threat demands a theoretical foundation which is able to prove that children are bearers of individual rights. ${ }^{18}$

\subsection{Theoretical background}

The debate on the exact nature of children's rights is certainly not new. Over the years it has acquired different nuances, but in general it is constituted of two main opposing views. First of all, there are those who claim that children do not or should not be treated as rights holders. Namely, the supporters of the so-called 'power' or 'will' theory stipulate that only those who have volitional capacities, or in other words have the power to claim and exercise their rights, could be deemed as rights bearers. Such theorists argue that rights are understood as the 'normative powers to determine the obligations of others' after the rights bearer has exercised his or her will. ${ }^{19}$ Since it could be the case that children are not able to articulate their will and demonstrate preference, it can be concluded that they may not be autonomous rights holders.

Others go on to argue that children's needs are much better protected when society's obligations towards them, for instance obligations on the side of institutions and parents, are well defined. This argument follows the logic that fundamental rights are rather blurred and frequently do not provide clear guidance on what is to be the result and the exact implication of these rights and the resulting obligations. ${ }^{20}$

\footnotetext{
${ }_{17}$ Stalford, Hollingsworth and Gilmore (n 13) 10.

${ }^{18}$ M Klaassen and P Rodrigues, 'The Best Interests of the Child in EU Family Reunification Law: A Plea for More Guidance on the Role of Article 24(2) Charter' (2017) 19(2) European Journal of Migration and Law 191, 198.

19 T Campbell, 'The Rights of Minors: As Persons, as Child, as Juvenile, as Future Adult' (1992) 6(1) International Journal of Law, Policy and the Family 1, 2.

20 O O’Neill, ‘Children's Rights and Children's Lives' (1992) 6 International Journal of Law and the Family 24, 39.
} 
The first objection to the idea that children could not be regarded as autonomous rights bearers is premised on the idea that there is a privileged group of rights holders who qualify as rights bearers by meeting certain criteria. This theory not only disregards the fundamental character of the idea of the universality of human rights, but also could deny the autonomous rights not only of children, but of many social groups, which do not 'meet' the pre-set conditions. ${ }^{21}$ The conclusion that this theory reaches is that rights can result in certain implications and obligations only for those that can demand them. It can be inferred that small children, who have no capacity to claim their rights, have no rights. A possible caveat which will allow the power theory to go around this striking logic is that a given proxy, such as the parent, may exercise certain 'discretionary powers' on behalf of the child, which would cover the child's needs. ${ }^{22}$ However, the rights bearer in question will still be the one exercising power and being the ultimate rights holder. A possible counter-argument to this claim is that once a proxy exercises his or her power in order to promulgate the interests of a child, it follows that the child has rights in the first place, which are the very foundation for the exercise of the claim by the proxy. ${ }^{23}$

The second view basically argues that in caring for children's needs, consideration should not be given to children's fundamental rights, as they do not provide guidance on the resulting obligations. Rather, the accent should be put on the duties that the different societal actors have visà-vis children in determining children's welfare. ${ }^{24}$ This rather paternalistic approach could perhaps function in an ideal scenario, in which the societal actors are fully sustainable, always have the best interest of the child at the centre of their actions and, last, it should be ascertained that the interests of these actors coincide with the interests of the child. The achievement of such perfect conditions, however, is quite impossible, given the numerous social and family unit abruptions which may occur. ${ }^{25}$ As other authors have also argued, the idea that children's interests always

\footnotetext{
21 Campbell (n 19) 3.

22 ibid.

23 ibid, 4.

${ }^{24}$ Some authors claim that such reasoning turns children into objects, rather than subjects of rights whose welfare is decided for them, thus preventing children from possessing rights in any 'meaningful sense'. See J Eekelaar, 'The Importance of Thinking That Children Have Rights' 6(1) International Journal of Law and the Family 221.

${ }^{25}$ For instance, Eurostat data for 2017 demonstrate that the number of marriages in the EU continues to fall, while the number of divorces increases. Eurostat, 'Marriage and Divorce Statistics' (Eurostat, June 2018) <http:/ /ec.europa.eu/eurostat/statistics-explained/ index.php/Marriage_and_divorce_statistics> accessed 15 April 2018.
} 
coincide with the interests of the parent is simply wrong. ${ }^{26}$ Furthermore, occurrences such as Brexit could stir and shake the very foundations upon which the given institutional narrative functions. In times of change and instability, it is crucial that there is a strong legal approach to determining the application and derived obligations for the realisation of the children's human rights in question. A theory which recognises that the interests of children could be of such crucial significance that they need to be protected by rights is therefore much sounder in terms of contributing to the protection of the needs of this vulnerable social group. ${ }^{27}$

\subsection{European law background}

From a historical perspective, children's rights seem to be drawing ever-greater attention in European legal discourse. ${ }^{28}$ However, even if children and children-specific issues are being increasingly referred to, criticism has been voiced that their rights are mostly framed as an additive to their parents' rights. To illustrate, some claimed that children are 'passive beneficiaries or victims of derived entitlement and their status is very much a consequence of their parents' employment status and relationships; they are the invisible appendages of the breadwinning migrant family'. ${ }^{29}$ This conclusion is inevitably based on the tension inherent in the nature of EU citizenship between market and Union citizenship. Arguably, market citizenship is the more developed strand, as it consists of rights which in fact represent active and passive market rights, which formed the very basis of European law. ${ }^{30}$ Union citizenship, on the contrary, refers to the rights granted to every EU citizen as such,

\footnotetext{
${ }^{26}$ H Stalford, Children and the European Union: Rights, Welfare and Accountability (Modern Studies in European Law, vol 32, Hart Publishing 2012) 48. Some authors look into the collision between extreme religious views and the protection of children's rights: C Shelley, 'Beating Children Is Wrong, Isn't It? Resolving Conflicts in the Encounter between Religious Worldviews and Child Protection' (2013) 15(2) Ecclesiastical Law Society 130.

27 Campbell (n 19) 5.

${ }^{28}$ L Ackers and H Stalford, A Community for Children? Children, Citizenship, and Internal Migration in the EU (Research in Migration and Ethnic Relations Series, Ashgate 2004) 199; Stalford (n 12) 212.

${ }^{29}$ L Ackers and H Stalford, 'Children, Migration and Citizenship in the European Union: Intra-Community Mobility and the Status of Children in EC Law' (1999) 21 Children and Youth 987, 1007.

${ }^{30}$ Market citizenship is said to connect the freedoms granted to EU citizens by the EU treaties to the functioning of the internal market. On the basis of this process, EU citizens can exercise active market rights, such as the freedom to pursue economic activity throughout the Union, and passive market rights, like consumer protection rights. For more, see P van Dijk (ed), European Community Law and Rights in Europe (Collected Courses of the Academy of European Law 1995, vol 6, book 1, Martinus Nijhof Publishers 1998) 169; J Shaw, 'Citizenship of the Union: Towards Post-national Membership?' (1998) <https://jeanmonnetprogram.org/archive/papers/97/97-06-.html> accessed 21 November 2018.
} 
regardless of whether the market citizenship aspect has been activated and there has been cross-border economic activity. ${ }^{31}$ The debate on the exact nature of EU citizenship has taken quite opposing views, from defining the status as an 'exercise in public relations', to concluding that it has evolved in such a way that is has become a "new fundamental freedom beyond market integration'. ${ }^{32}$ In any case, the status of EU citizenship represents a unique supranational legal structure, which could be criticised for adapting its implications to the characteristics of the holder. ${ }^{33}$

Even so, the phenomenon of EU citizenship has dramatically altered the state of the debate on citizens' rights in the European Union. The exact scope and limits of the consequences stemming from the status of Union citizenship could best be observed when applied to some of the most vulnerable groups in society, such as children. As non-market actors under EU law (and if bearing the nationality of a Member State) children can be defined as holders of the Union citizenship status, as outlined above. It could be inferred that the inconsistencies in the nature of EU citizenship are to colour the implication of this status when it comes to defining its implication for children.

The protection of the rights of the child are laid down in two fundamental sources of EU law, namely the Treaty on European Union (TEU) and the Charter of Fundamental Rights of the European Union, which has acquired the status of primary law since the Treaty of Lisbon entered into force. ${ }^{34}$ Specifically, Article 3 TEU defines the protection and promotion of children's rights as one of the objectives of the Union. Article 24 of the Charter defines the fundamental rights of the child in three steps. In the first place, it recognises the children's right to protection and care. Then, it goes on to assert that children can express their views freely and that these views are to be taken into consideration, in line with the child's age and maturity. It might seem paradoxical that the reference towards the importance of the child's will is preceded by the declaration of

\footnotetext{
${ }^{31}$ F Wollenschläger, 'A New Fundamental Freedom beyond Market Integration: Union Citizenship and Its Dynamics for Shifting the Economic Paradigm of European Integration' (2011) 17(1) European Law Journal 1, 1.

${ }^{32}$ F Wollenschläger, Grundfreiheit ohne Markt: Die Herausbildung der Unionsbürgerschaft im unionsrechtlichen Freizügigkeitsregime (Verfassungsentwicklung in Europa vol 2 [Unveränderter Nachdruck 2017 der Ausgabe von 2007], Mohr Siebeck 2017) 2.

${ }^{33}$ D Kochenov, 'Ius Tractum of Many Faces: European Citizenship and the Difficult Relationship between Status and Rights' (2009) 15(2) Columbia Journal of European Law 169. Charlotte O'Brien argues that in the current EU citizenship framework 'rights do not attach to personhood; rather rights are triggered, interpreted, delineated and weighed according to a miscellany of conditions'. See O'Brien (6) 1643.

${ }^{34}$ Case C-34/09 Gerardo Ruiz Zambrano v Office national de l'emploi ECLI:EU:C:2010:560, Opinion of AG Sharpston, para 61.
} 
the child's right to protection and care. Yet, children are inherently dependent on the care of others and the right to care comes as a precondition to the realisation of any other child-related right, including the child's right to freedom of expression. Secondly, Article 24 refers to the primacy of the principle of best interest, which is to guide the action of societal actors in all dealings regarding children. Finally, it is stipulated that children are to be able to have contact on a regular basis with both of their parents, as long as this is not in contradiction with their own interest.

Article 24 of the Charter is in fact 'directly inspired' 35 by the provisions of the United Nations Convention on the Rights of the Child, incorporating some of the most prominent CRC principles, such as, for instance, the best interests of the child principle (Article 3 of the Convention). The EU, being a non-state actor, does not have the possibility of becoming a party to the CRC. ${ }^{36}$ Yet, it is settled case law that the Union must respect international law in the exercise of its powers. ${ }^{37}$ In addition, being ratified by all of the 28 Member States, the CRC is already embedded in and intertwined with European legal discourse, which respectively entails that the EU has to observe the Convention's provision in all of its actions concerning children. ${ }^{38}$

\subsection{The children-related approach}

European law has experienced a shift towards greater recognition of the best interest principle and the specific rights of the child, listed in Article 24 of the Charter, by judicial incorporation of the concept of 'children's equilibrium'. ${ }^{39}$ The legal recipe for the achievement of such equilibrium, however, is still unclear. An incoherent approach towards children's rights may be well observed in the lack of comprehensive engagement with the relation between children's individual rights, their status of EU citizenship, and the emotional and financial dependency between children and their third-country national parents or carers. Yet, the examination of such omissions, taken together with the direction of the chronological development of the Court's reasoning, suggests what a child-related approach required for the reaching of children's equilibrium might consist of.

\footnotetext{
${ }^{35}$ FRA, European Union Agency for Fundamental Rights, Handbook on European Law Relating to the Rights of the Child (Handbook/ FRA, European Union Agency for Fundamental Rights, Publications Office of the European Union 2017) 27.

${ }^{36}$ Stalford (n 12) 214.

${ }^{37}$ For instance, in Case C-286/90 Poulsen and Diva Navigation ECLI:EU:C:1992:453, para 9; Joined Cases C-402/05 P and C-415/05 P Kadi and Al Barakaat International Foundation $v$ Council and Commission ECLI:EU:C:2008:461, para 291.

${ }^{38}$ Stalford (n 12) 215.

${ }^{39}$ Case C-82/16 KA (n 11) paras 71-72.
} 
A children-related approach in the interpretation of European law examines the relevant provisions or questions through the prism of children's specific rights, ${ }^{40}$ by acknowledging the ability of children to be independent rights bearers. ${ }^{41}$ Apart from being inspired by omissions in the related case law, the aforementioned statement also bears on the constitution of Article 24 of the Charter and the inseverable relationship between children's rights in the Charter and the CRC, as described above. Since the Charter directly 'translated' some of the most important CRC principles into EU law, identically to the $\mathrm{CRC},{ }^{42}$ the Charter also strives towards establishing children as rights bearers, rather than aiming to promulgate the welfare understanding of the children's best interest.

A child-related approach in EU law looks into the specific rights of the child, by interpreting them under the "umbrella ${ }^{943}$ of the best-interest principle and recognising the 'symbiotic relationship between interests and rights. ${ }^{44}$ One could come to wonder how the status of EU citizenship, for instance, could be elaborated upon by the utilisation of the children-related approach. It can be argued that when it comes to children, the elaboration of the substance of the status of Union citizenship requires recourse to the fundamental rights of the child, listed in either the Charter or the CRC, since they reflect the special interest of the child, comprising his or her equilibrium. Children's fundamental rights can thus guide the specific tailored application of this status, in order to ensure the protection of children's individual interests. For instance, the fact that children, especially small children, are unable to take advantage of the rights to freedom of movement on their own should inevitably be taken into consideration. The assessment of the 'genuine enjoyment' of the status of Union citizenship must therefore recognise the various issues surrounding the problem of children's dependency to the respec-

\footnotetext{
${ }^{40}$ Stalford, Hollingsworth and Gilmore (n 13) 3.

${ }^{41}$ Some authors argue that the purpose of the CRC was to establish children as bearers of individual rights. See CM Smyth, The Common European Asylum System and the Rights of the Child: An Exploration of Meaning and Compliance (Doctoral thesis, Leiden University 2013) 26.

${ }^{42}$ In relation to the CRC, Smyth argues that there is a fundamental contradiction between the paternalistic determination of someone else's welfare and the very idea of what it means to have a right'. See Smyth (n 41) 26.

${ }^{43}$ Klaassen and Rodrigues (n 18) 198.

${ }^{44}$ Smyth (n 41) 26-32. The expression 'symbiotic relationship' refers to four aspects which form the interaction between the best interest principle and the rights of the child. Namely, it could be stated that first, the best interest informs the meaning of the rights; then, vice versa, children's rights shape the meaning of the best interest; the best interest also represents a composition of rights; and, finally, the best interest could act as an independent provision alongside the substantive rights, requiring that the best interest is a primary consideration in all actions related to children.
} 
tive provision of care, in addition to the other specific interests of the child, enshrined in the rights in Article 24 of the Charter.

So far, only 'a handful of cases' directly concerning children's rights have been brought to the attention of the ECJ ${ }^{45}$ which has also been hesitant in engaging directly with the provisions of the CRC. ${ }^{46}$ Arguably, in comparison, the relationship between the jurisprudence of the European Court of Human Rights and the CRC has been much more productive and has even contributed to the development of the international children's rights standards. ${ }^{47}$ Namely, in relation to the right to family life, the European Court of Human Rights has developed a specific 'child-centred approach', which involves not only the assessment of the related positive and negative obligations, ${ }^{48}$ but also considers children's individual interests in the cases. ${ }^{49}$

Despite the lack of extensive reference to the CRC, the Court has promulgated that the $\mathrm{CRC}$ is a human rights instrument which is to be taken into account in the application of the general principles of European law. ${ }^{50}$ The fact that the Court has not engaged extensively with the Convention would not be troubling if the CRC principles were upheld and respected throughout the judgments concerning children, regardless of whether these principles were derived on the basis of the Convention or the European Charter. As the next part on children's freedom of movement rights will illustrate, the ECJ has engaged with children's rights and children's specific needs in an inconsistent manner, which, however, has evolved in the direction of the adoption of the children-sensitive interpretation of EU law.

\section{Children's freedom of movement rights}

The next part of the article will look into how European legal discourse has interpreted the law on freedom of movement in relation to children. It will be demonstrated that the discussion on children's specific needs has been increasing throughout the case law, yet this has occurred in a sporadic manner, which does not provide sufficient guidance on the interpretation of children's fundamental rights and their relation

\footnotetext{
45 ibid, 220.

${ }^{46}$ ibid, 221.

${ }^{47}$ For an examination of the protection of children's rights under the ECHR and on the backdrop of the CRC, see U Kilkelly, 'Protecting Children's Rights under the ECHR: The Role of Positive Obligation' (2010) 61(3) Northern Ireland Legal Quarterly 245.

48 ibid, 249.

49 ibid, 250.

${ }^{50}$ Case C-540/03 European Parliament v Council of the European Union ECLI:EU:C:2006:429, para 37.
} 
to the freedom of movement law. One of the main reasons is that there is a dichotomy in the understanding of whether children can be autonomous bearers of the status of EU citizenship and the related freedoms. It could be claimed that this discrepancy has its roots in the theoretical debate on the nature of children's rights, described in the previous part. Namely, when the Court debated on children's individual rights, children's own freedom of movement rights were examined in the light of children's specific needs.

However, in many instances the Court ignored the discussion on children's own rights, and rather focused on the rights of the parents or carers in the case. This manoeuvre adopts the paternalistic welfare approach towards children's best interest and assumes that other societal actors are proxy for the rights of the child, rather than recognising or at least considering the child's own legal prerogatives. In such instances, children's own rights are in fact denied their autonomous nature and are tied to and become dependent on EU citizenship (or lack thereof) and/or the freedom of movement rights of their parents. Still, the case law of the Court has demonstrated a cautious, but progressive step-by-step ${ }^{51}$ evolution in acknowledging that children's specific needs have to be part of the equation on the realisation of the freedom of movement rights under EU law.

\subsection{Children's entitlement to care and the right to family life}

Children's entitlement to care came to the fore of case law slowly, by initially being included in the legal discussion 'through the back door', as a follow-up result from the protection of the rights of the European breadwinning migrant. This approach was undertaken in the case of Carpenter, ${ }^{52}$ where the Court decided that a UK national, Mr. Carpenter, living in Great Britain and travelling often to provide services in other Member States, could rely on Article 56 TFEU, which concerns the free movement of services, so as to prevent the UK authorities from denying a residence permit to his third-country national spouse, who was taking care of his children from Mr Carpenter's first marriage. Mrs Carpenter is a Philippine national, who overstayed her leave in the UK and married Mr Carpenter, while being illegally present in the country. The ECJ decided that the refusal of a residence permit for Mrs Carpenter would obstruct the right to freedom of services of the EU citizen. ${ }^{53}$

\footnotetext{
${ }^{51}$ Koen Lenaerts argues that the EU citizenship judgments of the ECJ require slow consensus-building evolution. Thus, judgments need to be examined on the background of the preceding related case law. See K Lenaerts, 'EU Citizenship and the European Court of Justice's 'Stone-by-Stone' Approach' (2015) 1(1) International Comparative Jurisprudence 1.

${ }^{52}$ Carpenter (n 7) para 44.

53 ibid, para 38.
} 
Therefore, a decision to deport Mrs Carpenter would be disproportionate,$^{54}$ since she is considered as being part of the Carpenter family. Afterwards, the ECJ went on to examine the actions of the UK authorities in relation to Article 8 of the European Convention of Human Rights. The judgment is therefore directed towards enabling Mr Carpenter to continue to exercise his free movement rights, which is also confirmed by the lack of discussion on the position of the children in the case. Yet, in doing so, the ECJ used the act of caring for stepchildren in the assessment of the genuine character of family life. ${ }^{55}$ Thus, even if the primary focus was on securing the interests of the adult EU citizen, the Court willingly or unwillingly employed the aspect of child care as being the trigger for the subsequent applicability of the right to family life in the case. A possible deduction from the reasoning of the case is that the rights to reside and be treated equally on the basis of the EU freedom of movement law are to be interpreted with regard to the right to family life. ${ }^{56}$ The latter was challenged and undermined in various ways in the following judgments, regardless of being one of the main building blocks of a child-related approach.

\subsection{Children's specific needs and the right to education under Regulation No 1612/68}

While in Carpenter the main rationale of the judgment was related to the safeguarding of the free movement rights of Mr Carpenter, in Baumbast a main part of the judicial reasoning concerned the rights of the children, which were granted on the basis of the initial economic activity of the adult EU citizen. The similarity between both judgments is that even though the original reason behind the judicial reasoning was grounded on the protection of market citizenship, which treats children as additives to the working adult, the cases resulted in contributing to the recognition of the specific interests of the children involved. Baumbast represents how children's specific needs, combined with their right to education, stemming from Regulation No 1612/68, were the lever for the grounding of the residence rights of a third-country national carer. ${ }^{57}$ Mr Baumbast was of German nationality and had established his family and himself in the UK, where he had originally been engaged in business activity. His family consisted of Mrs Baumbast, a Colombian national,

\footnotetext{
54 ibid, para 43.

55 ibid, para 18.

${ }^{56}$ C O’Brien, 'Commentary on Case C34/09 Zambranov Office national de l'emploi' in Helen Stalford, Kathryn Hollingsworth and Stephen Gilmore (eds), Rewriting Children's Rights Judgments: From Academic Vision to New Practice (Hart Publishing 2017) 540.

${ }^{57}$ Case C-413/99 Baumbast $v$ Secretary of State for the Home Department ECLI:EU:C: 2002:493.
} 
her natural daughter, a Colombian national, and the daughter of $\mathrm{Mr}$ and Mrs Baumbast, who had double German and Colombian nationality. The children were enrolled in the educational system of the host Member State. Eventually, Mr Baumbast stopped working in the UK and redirected his business activities towards non-EU countries. Hence, the British authorities concluded that he was no longer a worker within the EU law definitions. The UK authorities sought to understand whether the right to education, granted by Article 12 of Regulation No 1612/68, ${ }^{58}$ would imply that children are entitled to residence in a host Member State if 'the parents have meanwhile divorced, that only one parent is a citizen of the Union and that parent has ceased to be a migrant worker in the host Member State or that the children are not themselves citizens of the Union'. ${ }^{59}$ Further, the referring tribunal sought to ascertain whether the right to education could create coterminous residence rights for the children's primary carer, regardless of his or her nationality.

The ECJ argued that declined residence permits would have the effect of preventing a child of a European citizen from continuing education in the host country by not allowing the worker to remain in the state. ${ }^{60}$ Once a child has settled in the Member State, an obstruction to the exercise of the right to access to education granted by Article 12 of Regulation No 1612/68 became an impediment to the right to freedom of movement. Therefore, no changes in the circumstances, such as the fact that the parent who is an EU citizen has ceased to work in the host Member State, could result in the denial of residence, for the sake of the realisation of the right to education. Furthermore, when the child has been enrolled in the education system, the primary carer, irrespective of his or her nationality, has the right to reside with the child for a period coterminous with the duration of the education.

The judgment in Baumbast portrays how the realisation and actual implementation of the right to education required that the care-related ties of children be protected. The combination of children's specific needs and the right to education could be one of the reasons why the ECJ anchored the residence rights of the third-country national spouse to the right of access to education of the children, rather than defining it as a derivative right stemming from the EU citizenship rights of the worker. Furthermore, the discussion regarding the family's finances and the requirement that beneficiaries of the right to freedom of movement are not to become an unreasonable burden for the host Member State was carried out against the background of Mr Baumbast's residence rights

\footnotetext{
58 Nowadays, Regulation No 492/2011 and respectively Article 10.

${ }^{59}$ Baumbast (n 57) para 39.

60 ibid, para 52.
} 
in the UK, while the residence rights of the children were not questioned at all. ${ }^{61}$

This approach of the Court, ie safeguarding the children's freedom of movement right and the related right to education, and the encompassing entitlement to care, ${ }^{62}$ goes a step further in the case of Ibrahim. ${ }^{63}$ The judgment concerns a family, in which a Danish citizen, Mr Yusuf, had worked in the UK for some time, where he lived with his Somali wife, Ms Ibrahim. The couple had four children who were of Danish nationality; the two eldest of them enrolled in the education system of the host state. After the father lost his job, he left the country and stopped providing for his family. Ms Ibrahim was never self-sufficient, nor possessed health insurance, and counted on social assistance in order to support her family. In January 2007 Ms Ibrahim applied for housing assistance for herself and her children. ${ }^{64}$ The request was denied with the argument that she could not qualify as a resident in the UK under European law. She appealed against this decision and eventually the Civil Division of the Court of Appeal of England and Wales decided to enquire whether she had a right of residence based on Article 12 of Regulation 1612/68 given that she did not meet the conditions of Directive 2004/38. ${ }^{65}$

The Court concluded that the right of access to education was not conditional on the retention of any specific residence right by the children. Once they had become part of the host state's educational system, the right to education acquired independent status from the rest of the conditions in Regulation and Directive 2004/38 governing the residence rights in the Union of EU citizens and their families. As a primary carer, the mother could claim a residence right on the basis of the care she provided for the realisation of the right to education of her children, without the need to possess sufficient resources and comprehensive sickness insurance in the UK. ${ }^{66}$ Hence, the right to education in the case brought to the forefront the consideration of aspects which are fundamental to

\footnotetext{
${ }^{61}$ ibid, paras 90-92.

${ }^{62}$ In a 'rewritten' judgment of Case C-34/09 Zambrano, presenting what the legal reasoning could look like if it was following a children's rights-based approach, Charlotte O'Brien argues that the foundations for the granting of residence rights to the third country national carer in Baumbast were the children's best interests and the right to education. See O'Brien (n 56) 542.

${ }^{63}$ Case C-310/08 London Borough of Harrow v Nimco Hassan Ibrahim ECLI:EU:C:2010:80, para 59.

${ }^{64}$ ibid, para 21.

65 ibid, para 24.

${ }^{66}$ The same conclusion was reached again also in the more recent judgment in Case C-115/15 Secretary of State for the Home Department v NA ECLI:EU:C:2016:487, paras 64-67.
} 
the creation of a child-related approach for the achievement of children's equilibrium, most notably by stressing children's entitlement to care.

Some authors argue that the construction of the freedom of movement discourse is done in such a way as to exclude the recognition of unpaid labour, such as the provision of care. ${ }^{67}$ In order to be able to derive equal treatment rights on the basis of EU free movement law, third-country national carers need either to be part of the family of an EU migrant worker or provide care for the children of such a worker. ${ }^{68}$ The fact that the provision of care per se is unable to trigger any rights stemming from EU legal discourse leads to unbalanced development in relation to the protection of children's interests. Namely, 'so that someone present in a host State for four and a half years, with a couple of pre-school age children, may face a welfare cliff edge as compared to someone present for a few months whose child is enrolled in school'. ${ }^{69}$

Indeed, the origin of the granting of the right to education is the economic activity of the migrant worker. Yet, the case of Ibrahim clearly illustrated the evolution of the freedom of movement right to education, which was shaped by the specific needs of the children in the related cases. The right has obviously outgrown its initial ancillary purpose (supporting the economic activity of the EU citizen), by becoming independent of the rest of the provisions in Regulation 1612/68. The right extended its material scope in such a way as was necessary for its realisation, including by taking into account the children's entitlement to care as a precondition for their ability to carry on their studies.

\subsection{Children's specific needs and EU citizenship status}

The examination of the development of the right to education under Regulation No 1612/68 might suggest that the European free movement framework increasingly upholds the stance that it grants children rights which eventually acquire independent status. ${ }^{70}$ However, an examination of children's independent rights as EU citizens demonstrates a nuanced picture in relation to the recognition of children's specific needs. Even if the consideration of children's specific needs has occupied greater attention in the EU citizenship case law, there is still a lack of in-depth analysis of children's fundamental rights.

Attention to children's specific needs is crucial, because, given their age and maturity status, they can hardly utilise their free move-

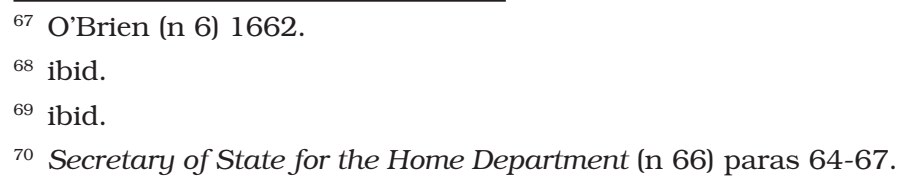


ment rights in order to be defined as 'market citizens'. Therefore, children can rather be regarded as holders of the 'market citizen' classification, described above, which in turn begs the question of how 'Union citizenship' is to be understood when applied to children.

The case law of the ECJ demonstrated that children should be perceived as full beneficiaries of the status of EU citizenship on the basis of Article 21 TFEU if they bear the nationality of one of the Member States. This argument is well illustrated in the case of $Z h u$ and Chen, in which the Chinese mother of baby Catherine, at the time of the proceedings living in Cardiff, Wales, gave birth to her daughter in Northern Ireland. In this way, via jus soli, the baby acquired Irish nationality. ${ }^{71}$

The Irish and UK governments claimed that the entitlements and rights of children depended on the exercise of free movement and considered the situation in question as purely internal. The Irish government adopted the argumentation of the 'will' theory by arguing that being a child, Catherine is 'unable to assert a choice of residence in her own right', and thus cannot be regarded as a rights bearer under European law. ${ }^{72}$ However, as Advocate General Tizzano stated in his opinion, the fact that a child "cannot exercise a right independently does not mean that he has no capacity to be an addressee of the legal provision on which that right is founded. ${ }^{73}$ The Court seemed to agree, and stated that the child should be able to benefit from the fundamental freedom of residence, granted by Community law. ${ }^{74}$ Furthermore, in order for baby Catherine $\mathrm{Zhu}$ to be able to take advantage of her EU citizenship rights, her third-country national mother, being her primary carer, should be granted residence rights, as long as she has sufficient resources. ${ }^{75}$

The factual background of the case prevents reference to the dependency definition, developed by the Court in relation to Regulation No 1612/68, which stipulates that the 'dependent' one is the person for whom the holder of the residence right is providing material support. ${ }^{76}$ The situation at stake provides the opposite scenario, in which the bear-

\footnotetext{
${ }^{71}$ In accordance with section 6(1) of the Irish Nationality and Citizenship Act of 1956 any person born on the island or Ireland can acquire Irish nationality. Section 6(3) of the same Act states that any person born on the island of Ireland who is not entitled to citizenship of any other country is an Irish citizen from his or her birth. In contrast, the UK does not grant British nationality on the basis of jus soli. See Case C-200/02 Zhu and Chen ECLI:EU:C:2004:639, paras 8-10.

${ }^{72}$ Case C-200/02 Zhu and Chen ECLI:EU:C:2004:307, Opinion of AG Tizzano, para 42.

${ }^{73}$ ibid, para 44.

${ }^{74}$ Zhu and Chen (n 71) para 40.

75 ibid, para 47.

${ }^{76}$ Case 316/85 Centre public d'aide sociale de Courcelles $v$ Marie-Christine Lebon ECLI:EU:C:1987:302, paras 20-22.
} 
er of the residence right is the one who is dependent on the support of the third-country national carer, who seeks the right to residence. Even though the dependency definition of Regulation No 1612/68 was inapplicable to the case, the ECJ referred to Article 12 of the same Regulation and to the judgment in Baumbast in order to stress the indivisible relation between a child's right to residence and his or her entitlement to care. Apparently, in doing so, the Court was driven by an inclination to uphold children's special needs, but unfortunately failed to do so explicitly with regard to the construction of a child-related approach.

Children's EU citizenship status became the basis for one of the highly debated judgments in the case of Ruiz Zambrano. ${ }^{77}$ The judgment background concerned the residence and work permit rights of the Colombian father of children with EU citizenship. Mr Zambrano had arrived in Belgium with his wife and son, where they sought asylum. The applications were refused, but the family was allowed to remain in the country due to the worsening situation in their country of origin. $\mathrm{Mr}$ Zambrano applied on a few occasions to have their residence situation regularised, but the requests were denied. Even though he did not have a work permit, Mr Zambrano became a full-time employee. In the course of time, the family had two more children, who were granted Belgium nationality. Later Mr Zambrano's employment was temporarily suspended and he applied for unemployment benefits, leading to an inspection at his employer and the immediate termination of Mr Zambrano's contract. In the appeal proceedings, Mr Zambrano argued that 'at the very least' he could have a derived right of residence under European law on the basis of the ruling in Zhu and Chen. ${ }^{78}$

When the case ended up before the ECJ, all of the governments, submitting observations, argued that the situation could be defined as entirely internal, given that the children with EU citizenship had never left the Member State of origin..$^{79}$ The Court argued that the absence of the cross-border element implied that Directive 2004/38 was not applicable, but that the children, being citizens of Belgium, still fell under the application of Article 20 TFEU. ${ }^{80}$

In her opinion, Advocate General Sharpston argued that the exercise of the rights stemming from the status of EU citizenship was not necessarily tied to the exercise of physical movement. The line of EU citizenship case law demonstrates instances in which the cross-border element

\footnotetext{
${ }^{77}$ Case C-34/09 Gerardo Ruiz Zambrano $v$ Office national de l'emploi ECLI:EU:C:2011:124.

${ }^{78}$ ibid, para 34.

79 ibid, para 37.

80 ibid, para 40.
} 
is either present in terms of the ties that the child with EU citizenship has with different Member States, rather than with actual movement. ${ }^{81}$ The crucial aspect in the case was that regardless of whether a situation is internal or not, 'Article 20 TFEU precludes national measures which have the effect of depriving citizens of the Union of the genuine enjoyment of the substance of the rights conferred by virtue of their status as citizens of the Union'. ${ }^{82}$ The denied requests for residence and work permits of $\mathrm{Mr}$ Zambrano could entail that the family would naturally be forced to leave the borders of the Union, depriving their children of the possibility to realise their rights stemming from their EU citizenship.

The conclusion of the Court sparked many debates on what the genuine enjoyment of EU citizenship rights actually entailed. Some went on to conclude that the scope of the implication of the judgment in Zambrano was quite narrow and referred to extreme scenarios, where the refusal of a residence permit to the third-country national would force EU citizens to leave the Union as a whole. ${ }^{83}$ In addition, concerns were raised that the reasoning of the Court concerned solely the granting of residence rights, by leaving aside the issues of social and economic rights. In doing so, the decision in fact deprives the EU citizenship status of any 'useful effect', ${ }^{\prime 4}$ by in fact telling the Zambrano children that due to EU law they could just reside in the Member State, without having any related social rights in order to be able to actually do so. In such a case, it is safe to assume that in the face of the risk of destitution, the children would have to leave the Union with their father.

A 'revised' version of the judgment, which recognises children's specific needs, would take into account Article 24 of the Charter, by also stressing the importance of reading the Charter in the light of the CRC, given that the Convention is ratified by all Member States. ${ }^{85}$ Indeed, Zambrano did not examine the genuine enjoyment of the status of European citizenship through the children's rights to family life and their rights as children, which creates blurriness in relation to the judgment's exact scope and application. Undoubtedly, the children's entitlement to care and the fact that the minors in the case are the bearers of Union citizenship status led to the protection of the residence rights of the father. However, this does not shed light on whether the mother of the chil-

${ }^{81}$ Of the cases concerned, Advocate General Sharpston refers to Garcia Avello (n 9) and Zhu and Chen (71). Case C-34/09 Gerardo Ruiz Zambrano $v$ Office national de l'emploi ECLI:EU:C:2010:560, Opinion of AG Sharpston, para 78.

82 Zambrano (n 77) para 42.

${ }^{83}$ A Hinarejos, 'Citizenship of the EU: Clarifying "Genuine Enjoyment of the Substance" of Citizenship Rights' (2012) 71(2) Cambridge Law Journal 279, 279.

${ }^{84}$ O'Brien (n 56) 543.

85 ibid, 542. 
dren could also benefit from the granted protection. A reference in the judgment to Article 24 of the Charter and specifically their best interest would imply that she should be able to do so, based on the provision referring to the right of children to maintain contact with both parents. Further, the lack of any discussion of the best interest of the children could be interpreted as entailing that the Court does not 'take children's rights seriously', despite the fact that, in general, the protection of the rights of the child is recognised as one of the main objectives of the European Union. ${ }^{86}$

In contrast to the judgment's lack of discussion on children's special needs, the opinion of the Advocate General refers to Article 24 of the Charter. AG Sharpston concluded that the decision of the Belgian authorities to deny Mr Zambrano a residence permit could result in a potential serious violation of the rights of children as such. ${ }^{87}$ Due to the care provided by their parents, denial of a residence permit implied that the children would have to leave the country where they had become integrated. ${ }^{88}$

The reasoning in the following judgment in Dereci ${ }^{89}$ also focused primarily on whether there was an existing dependency relationship between the third-country national and the European citizen(s). One of the cases in the joint judgment involved the applicant Mr Dereci, a Turkish national, who had entered Austria illegally in 2001, and then married an Austrian national in 2003. ${ }^{90}$ The couple have three children, all of whom possess Austrian nationality. The Austrian authorities refused to grant a residence permit to the father, and the Court did not consider that this would 'undermine the effectiveness' of the Union citizenship ${ }^{91}$ of the Member State national spouse. The mere fact that it may 'appear desirable' for the Union citizen to preserve her family together within the borders of her own state was insufficient for bringing the situation within the parameters of EU citizenship law. ${ }^{92}$ The difference with the factual background of the case in Zambrano was that the children were dependent on Mr Zambrano, while Mr Dereci was incapable of providing for them. ${ }^{93}$ Therefore, if dependency is understood in crude economic

\footnotetext{
${ }^{86}$ ibid, 534.

87 Opinion of AG Sharpston (n 34) para 62

88 ibid, para 63.

${ }^{89}$ Case C 256/11 Murat Dereci v Bundesministerium für Inneres ECLI:EU:C:201 1:734.

90 ibid, para 25; Case C-256/11 Dereci ECLI:EU:C:2011:626, Opinion of AG Mengozzi, para 7.

${ }^{91}$ Dereci (n 89) para 68.

92 ibid, para 68.

${ }^{93}$ Opinion of AG Mengozzi (n 90) para 7.
} 
terms, an eventual deportation of the father to his state of origin would not force the family to follow him.

As a separate issue, the ECJ suggested a separate examination of the issue whether a residence permit refusal could undermine the right to family life. ${ }^{94}$ This dividing of the different aspects of the case demonstrated that the Court indeed understood the idea of dependency solely in its financial dimensions, which could not be examined in the light of the right to family life. Furthermore, the concept of dependency was applied only in relation to the Austrian spouse, rather than to the children, who are also bearers of the status of EU citizenship. Similarly to the method used by the proponents of the 'will' theory, the mother is seen as the one who is able to exercise discretionary powers on behalf of the children. The approach can be criticised for circumventing the issue of the rights of the children in the case, who also possess their own EU citizenship statuses. Furthermore, the lack of financial dependency does not provide insight into the interpretation of children's fundamental rights, listed in Article 24 of the Charter, in the light of an eventual decision for deportation.

The main problem resulting from the approach in Zambrano and Dereci is that both judgments are short-sighted in relation to the protection of children's specific needs and the respective relevance of Article 24 of the Charter. By not taking account of the social rights applications of EU citizenship status, the Court risks stripping the concept of any sustainable meaning in cases where the rights bearers are children, ie actors who cannot activate their 'market citizenship' in order to activate the protection of their rights under EU law. A consequence is that Member States can tap into this lack of substantial safeguarding of the status of EU citizenship and use it to shape their legislations so that Zambrano-type applicants are surely banned from access to welfare benefits. The latter was illustrated in a decision by the UK Supreme Court, ${ }^{95}$ which affirmed that Zambrano granted solely residence rights to third-country national carers of children with EU citizenship: 'It is clear $[\ldots]$ that the reasoning of the [ECJ] turned specifically and solely on the risk of being obliged to leave the territory of the Union. There was no issue as to the nature of financial support (if any) required, nor as to the extent of any right to benefits otherwise available to nationals'. ${ }^{96}$ Hence, the matters related to any benefits were resolved under the matters of

\footnotetext{
${ }_{94}$ Dereci (n 89) paras 70-74.

${ }^{95} \mathrm{R}$ (on the application of HC) (Appellant) v Secretary of State for Work and Pensions and others (Respondents) [2017] UKSC 73.

96 ibid, para 9.
} 
national law. ${ }^{97}$ In this regard, after the judgment of the ECJ came out, the UK authorities were quick to amend the related national legislation so that it excluded from its scope Zambrano-applicants. Still, in doing so, they were in line with their obligations under European law, as the only thing required of them was to provide residence rights.

In her concurring opinion, Lady Hale agreed that the UK was not in breach of its EU law responsibilities. Yet, when examining the national law measures determining the social rights of Zambrano-families in the country, she called for a 'child-centred approach'98 in the administration of the domestic legislation, which recognised that children had the right to remain in their own country, but also needed the care of their mother, and 'the support of the state in the shape of a place to live and enough to live on'. ${ }^{99}$ Otherwise, supposing that the carer cannot work, since she has to provide care for her children, the whole family might in fact be forced to leave the EU. The last could actually imply a failure of the British authorities to comply with European law. ${ }^{100}$

\section{4 'Children's equilibrium': a goal for EU law interpretation?}

The previous part demonstrated how the lack of consideration of children's specific needs in the Court's case law on children's EU citizenship has led to it being a potential obstacle to the 'genuine enjoyment' of this status regarding its practical realisation. The judgments involving the free movement right to education brought forward various aspects and sometimes fundamental rights which could be seen as essential components of the child-related approach. Still, despite these positive aspects, the reasoning in these cases originated from the economic activity of the adult EU citizen and did not amount to the development of a child-sensitive interpretation of the law. Hence, the comparatively recent inclusion of Article 24 in the judicial discussion on children's EU citizenship status was a welcome development, especially given the background of the aforementioned past omissions or incomplete discussion on children's interests and their respective protection by rights.

Namely, in its later judgments, the ECJ started to consider further aspects in the assessment of whether European citizenship could be endangered. The Court enriched the genuine enjoyment test with several further factors, which are specifically directed towards covering children's specific needs: a multi-layered relationship of dependency (finan-

\footnotetext{
97 ibid.

98 ibid, para 51.

99 ibid.

100 ibid, para 48.
} 
cial, legal, and emotional), the right to family life, the best interest of the child, and other specific circumstances which could have an impact on 'children's equilibrium'101 (such as the age of the child, the child's physical and emotional development, and the emotional ties of the child with the third-country national parent).

One of the joint judgments in this regard involved numerous cases with no cross-border aspect, and concerned the residence rights of a third-country national parent who was the primary carer of a child with European citizenship. ${ }^{102}$ In most of the cases, the other parent, who also possessed European citizenship, did not provide support and/or did not take care of the child in question. The background thus presented favourable conditions for a clarification of the constitution of the child's own specific needs as an EU citizen, since the adult European citizens were either unable or unwilling to take care of the child or children. Therefore, an examination of the issues in the case could not be carried out on the background of the relationship between the child and the adult EU citizen ${ }^{103}$ who can exercise his or her EU market rights. Rather, the questions had to be examined on the basis of the children's own 'Union citizenship' status.

Given the circumstances, the Court stated that a decision on whether a child's genuine enjoyment of EU citizenship status could be threatened needed to acknowledge not only who has custody of the child, but also whether the child 'is legally, financially or emotionally dependent on the third-country national parent'. ${ }^{104}$ What is more, the deliberation must take into account the right to family life and the preservation of the best interest of the child. For this purpose, even if the other parent is able and willing to take care of the child, this would not suffice for the conclusion that the child's EU citizenship rights are preserved. What is required is a careful evaluation of the child's multi-faceted relationship with the third-country national parent, which is not limited to straightforward financial dependency. ${ }^{105}$

Furthermore, the latest judgments of the Court have underlined that the examination of whether a given national measure could infringe the child's EU citizenship status is to have due recourse to preserving

\footnotetext{
${ }^{101}$ KA (n 11) para 72.

102 Chavez-Vilchez (n 10).

${ }^{103}$ Similar to the approach of the Court in Dereci (n 89).

${ }^{104}$ Chavez-Vilchez (n 10) para 68.

105 ibid. In the recent judgment of KA (n 11), this conclusion was reiterated, by underlining that the assessment of the dependency relationship is to take account of art 7 and art 24 of the Charter (para 71).
} 
the 'children's equilibrium'. ${ }^{106}$ The reasoning of the ECJ demonstrates that the idea of the 'children's equilibrium' is undoubtedly grounded on Article 24 of the Charter, as it refers to the best interest of the child (stated in Article 24.2), the possibility of maintaining contact with both parents (as stated in Article 24.3), and recognition of the specific needs of the child (as stated in Article 24.1).

The interpretation of the legislation with the goal of achieving or maintaining a 'children's equilibrium' is indeed crucial in the elaboration of children's own rights under European law. Therefore, the novel introduction of the children-conscious consideration is a welcome advance, given the lack of child-sensitive reasoning in Zambrano-styled judgments. Still, the question remains of how these various aspects forming equilibrium are about to be interpreted in relation to European law, especially given the sporadic discussions of some of these rights in past cases.

To illustrate, reference to the best interest of the child does not provide information on the use of the provision in relation to European law since the ECJ was reluctant to utilise the term in relation to freedom of movement and EU citizenship law. In addition, as the overview of the case law has demonstrated, the interests of children were not always backed up by children's individual rights, but at times were seen as issues which are secondary to the problems of the adults. This approach creates the threat of the utilisation of a welfare-based understanding of the best interest of the child, which, as discussed in the previous part, is incompatible with the view that children are independent rights bearers.

In contrast, others have advocated a 'rights-based'107 understanding of the best interest principle, which strengthens the importance of children's individual rights. ${ }^{108}$ The Committee on the Rights of Children has stated that the best interest of the child is a threefold concept, which is composed of a substantive right, a fundamental, interpretative legal principle, and a rule of procedure. ${ }^{109}$ In discussing the concept, the Committee has stressed that it always refers to the three meanings at once. In addition, among other rights, including the best interest of the child enshrined in Article 3 of the Convention, the Committee has noted that children's rights contain various elements, which stresses the 'interde-

\footnotetext{
106 Chavez-Vilchez (n 10) para 71; KA (n 11) paras 71-72.

107 Smyth (n 41) 26.

108 Klaassen and Rodrigues (n 18) 198.

109 Committee on the Rights of the Child, 'General Comment No 14 (2013) on the right of the child to have his or her best interests taken as a primary consideration (Art 3, para 1)' (May 2013) para 6.
} 
pendence and indivisibility' of these rights. ${ }^{110}$ Therefore, the CRC could eventually provide a rich explanatory background for the scope of the child-related provisions of the Charter, ${ }^{111}$ if the Court is willing to provide leeway for the construction of comprehensive guidance on the interpretation of the 'children's equilibrium' and the child-related approach needed for its achievement.

\section{Post-Brexit and the rights of children}

The case law on children's EU citizenship status demonstrates that there has been a development in the interpretation of children's genuine enjoyment of this status, to put it plainly, from affirming that children are beneficiaries of Union citizenship, ${ }^{112}$ which grants them a sole residence right in the Union, to establishing that the genuine enjoyment of children's EU citizenship requires a child-related approach, aiming at maintaining 'children's equilibrium', ie the different types of needs that the child can have (legal, financial and emotional) and the preservation of the rights of the child under Article 24 of the Charter. ${ }^{113}$

In relation to the preservation of children's rights and fundamental rights in general, there are numerous concerns that Brexit will create loopholes in the protection of the rights of those who will be affected by the UK's withdrawal. ${ }^{114}$ In this regard, it is worthwhile to examine the state of the discussion on the UK's withdrawal and estimate to what extent the consideration of children's specific needs is included in the process. Since the main focus of the article is on European law, the following arguments are primarily directed towards the post-Brexit application of EU law in relation to the rights of children with UK citizenship residing in one of the other 27 Member States. For the sake of maintaining balance, however, the question of the removing of the freedom of movement law will be examined in the light of the CRC rights of children with EU citizenship residing in the UK.

\footnotetext{
110 The Committee has noted that 'Enjoyment of economic, social and cultural rights is inextricably intertwined with enjoyment of civil and political rights'. See Committee on the Rights of the Child, 'General Comment No 5 (2003) General measures of implementation of the Convention on the Rights of the Child (Arts 4, 42 and 44, para 6)' (November 2003) para 6.

${ }^{111}$ Stalford (n 12) 22.

112 Zhu and Chen (n 71).

${ }^{113}$ KA (n 11).

$114 \mathrm{~J}$ Cooper, 'The Fate of the Charter of Fundamental Rights in UK Law After Brexit Is Sealed' (Oxford Human Rights Hub, 20 June 2018) <http://ohrh.law.ox.ac.uk/the-fate-ofthe-charter-of-fundamental-rights-in-english-law-after-brexit-is-sealed/\#> accessed 19 October 2018; N Bamforth and others, 'The EU Charter After Brexit' (Oxford Human Rights Hub, 2018) <https://ohrh.law.ox.ac.uk/wordpress/wp-content/uploads/2017/11/TheEU-Charter-After-Brexit-.pdf> accessed 19 October 2018.
} 
Given the high level of legal uncertainty surrounding Brexit, one could assume that specific measures are undertaken in order to provide for the protection of children's rights during times of transition. Yet, consideration of children's rights in the negotiations is lagging behind and can benefit from the omissions in the children's freedom of movement case law, as discussed above.

\subsection{Consideration of children's rights in the Brexit negotiations}

The status of European citizenship will soon cease to be applicable to children with British nationality. ${ }^{115}$ However, UK citizens are not likely to be referred to as future third-country nationals for two reasons. First, they have enjoyed the freedom of movement rights and have shaped their lives alongside the process of European integration. Second, the debates on the content of the Withdrawal Agreement show that 'a reciprocal protection is to be applied to UK and EU citizens, in order for them to preserve the rights that they have acquired to enable the effective exercise of rights derived from Union law and based on past life choices'. ${ }^{116}$ The current state of the discussion is primarily focused on securing the continuation of the rights of citizens in the state where they are residing before Brexit day in 2019. The freedom of movement rights, being some of the core rights of EU citizenship, have not been settled upon. ${ }^{117}$ The Court is to have full jurisdiction during the transition period and, through a special mechanism, UK courts and tribunals should be able to submit to the former questions on interpretations of European law for up to eight years after the entry into force of the Withdrawal Agreement. ${ }^{118}$

Some have criticised both the European Commission and the UK authorities for failing to include the specific needs of children in their propositions for the residence rights of UK citizens in the EU, and, respectively, EU citizens in the UK. ${ }^{119}$ An important aspect in the assessment of post-Brexit residence statuses is that children's rights are not

\footnotetext{
${ }^{115}$ Except for those children, of course, who have dual nationality and are bearers of the citizenship of another Member State.

${ }^{116}$ Commission, 'Joint report from the negotiators of the European Union and the United Kingdom Government on progress during phase 1 of negotiations under Article 50 TEU on the United Kingdom's orderly withdrawal from the European Union' (European Commission, 8 December 2017) para 6 <https://ec.europa.eu/commission/publications/joint-report-negotiators-european-union-and-united-kingdom-government-progress-during-phase-1-negotiations-under-article-50-teu-united-kingdoms-orderly-withdrawal-european-union_en> accessed 14 April 2018.

117 Commission (n 116).

118 ibid, para 38.

119 Brexit and Children Coalition (n 16) 12.
} 
just taken as annexes to their parents' residence rights. Namely, children could be bearers of residence statuses which are different from those of their parents. ${ }^{120}$

A further concern is that the introduction of a mandatory application for residence status can be problematic for children as they will have to count on their parents initiating the application. It is feasible that the result will be the existence of children who will remain unregistered, or the fact that some of them could have problems in providing proof for the five years of residence required for obtaining settlement status. ${ }^{121}$ In addition, there should be special, independent mechanisms for children pursuing their studies, which can help them to acquire so-called 'settled status' which is to be granted to children with EU citizenship residing in the UK. ${ }^{122}$ The slow and unsteady evolution of the protection of children's rights illustrated in the previous part of the article demonstrated the difficult recognition and upholding of children's individual rights in cases where children were holders of EU citizenship status and could benefit from the freedom of movement law. The upcoming withdrawal of this status for children with UK nationality and the uncertainties surrounding the future of children with EU citizenship residing in the UK outline the yet unmarked territory of the ceasing of the functioning of the law on freedom of movement. All of the impediments surrounding the guaranteeing of children's equilibrium when the child was protected by the status of EU citizenship and freedom of movement rights suggest that once the child loses these prerogatives, he or she will be left somewhere in a vacuum between EU citizenship and being a third-country national, where consideration of his or her rights can be trumped by the overall situation of legal uncertainty.

The discussion of the case law in the previous part showed how the lack of a child-related approach, in other words the lack of recognition of children's own specific rights and the circumventing of their specific needs, is incompatible with the objective of children's equilibrium. By drawing lessons from the case law on children's rights under the freedom of movement law, in post-Brexit the preservation of the rights of the child could be aided by defining the maintenance of children's equilibrium as one of the main objectives of the Withdrawal Agreement which can be elaborated by the adoption of a specific child-related approach. As the ECJ has shaped it, children's equilibrium is to constitute one of the most fundamental children's rights and related principles, as enlisted in Arti-

\footnotetext{
120 ibid, 12 .

121 ibid.

122 ibid.
} 
cle 24 of the Charter. Furthermore, again on the basis of the omissions in the case law discussed above, the maintenance of children's equilibrium should be carried out in a child-centred approach based on examining and considering children's individual rights. The legal basis for the inclusion of the objective of 'children's equilibrium' can be the CRC, ${ }^{123}$ and the adoption of a child-related approach can be inspired by the legal traditions of the UK, ${ }^{124}$ the EU, and possibly the ECHR. ${ }^{125}$

The inclusion of children's equilibrium in the Withdrawal Agreement can balance the protection of children's rights in the post-Brexit period. To illustrate, it is still not clear what the consequences could be of the use of delegated powers which the UK Withdrawal Bill will grant the Government. ${ }^{126}$ To clarify, the latter is to allow the Ministers to amend related laws where they deem them 'appropriate' without initially undergoing parliamentary scrutiny. ${ }^{127}$ The time pressure and novelty of the situation may result in the 'erosion of rights' of children, ${ }^{128}$ which should be curbed by the obligations of the sides involved to maintain children's equilibrium.

Another significant drawback in the children-related freedom of movement case law pertained to the insufficient consideration of the best interest of the child. Yet, consideration of the best interest of the child is a base line for the full and effective enjoyment of all other children's rights in the CRC. ${ }^{129}$ Arguably, in addition to stating that the future actions of the authorities will have to be carried out in consideration of

\footnotetext{
${ }^{123}$ As mentioned before, the CRC is ratified by both the UK and the 27 Member States and therefore can be suitable as a basis due to its universal nature and the inapplicability of the European Charter in relation to the UK after Brexit day.

${ }^{124}$ Williams points out that the UK has not yet legislated to incorporate the CRC into the domestic legal order. Nonetheless, the Convention influences the decision of the courts, including when interpreting other treaties, and has formed part of the work of the devolved administration. See J Williams, 'England and Wales' in Ton Liefaard and Jaap E Doek (eds), Litigating the Rights of the Child: The UN Convention on the Rights of the Child in Domestic and International Jurisprudence (Springer 2015) 68.

125 The ECHR is a considerable source for the protection of children's rights in the UK. The impact of the Convention is amplified by the CRC, which contributes to the child-related interpretation of the former. See Williams (124) 54.

${ }^{126}$ Brexit and Children Coalition (n 119) 6. It is still not clear what the influence of the Parliament on the final Brexit deal will be. See P Walker, 'EU Withdrawal Bill: What Happens Next? With Brexiters and Remainers Insisting PM Has Guaranteed Their Preferred Outcomes, Further Clashes Look Inevitable' The Guardian (13 June 2018, London) <www. theguardian.com/politics/2018/jun/13/eu-withdrawal-bill-brexit-what-happens-next> accessed 3 August 2018.

${ }^{127}$ House of Lords Delegated Powers and Regulatory Reform Committee, 'European Union (Withdrawal) Bill' (February 2018) para $4<$ https://publications.parliament.uk/pa/ ld201719/ldselect/lddelreg/73/7304.htm> accessed 3 August 2018.

${ }^{128}$ Brexit and Children Coalition (n 16) 6.

129 Committee on the Rights of the Child (n 109) para 4.
} 
children's equilibrium, the designing and negotiating of the Withdrawal Agreements need to be carried out in conformity with the CRC. More specifically, as Article 3 of the CRC stipulates, all of the activities of the authorities affecting children need to take as primary consideration the best interest of the child. Therefore, the development of any legislative proposals needs to be in conformity with this principle, which can cushion the unpredicted effects that some of the Brexit-related consequences may have.

Of particular concern in this regard is the ambivalent situation of children in Northern Ireland. Approximately 23,000 people commute across the border daily, and there are almost two million cars per month crossing the north/south border. ${ }^{130}$ The cited numbers do not take account of other people, such as students going to schools or hospitals, who do not cross the border for non-work purposes. ${ }^{131}$ There are arguments that the lives of children in the area are often inherently connected to both the North and the South parts of Ireland. ${ }^{132}$ The UK's withdrawal from the EU is posing the threat of creating 'major instability for Northern Ireland particularly in the border counties and [posing] challenges for Westminster.'133

In this case the authorities need to recognise that Article 3 of the CRC grants them no discretion on whether children's interests need to be assessed when an undertaken action is to affect them. ${ }^{134}$ The carrying out of such an assessment first requires a best-interest assessment identifying all the relevant elements and then the best interest in question, ${ }^{135}$ and, second, the establishment of procedural safeguards to guarantee the implementation of this best interest. ${ }^{136}$ Such an assessment could be carried out also on a larger scale, encompassing a particular group of children. ${ }^{137}$ It could be argued that one of the elements in the determination of the best interest in the case would entail the preservation of the rights granted by the Good Friday (Belfast) Agreement during the post-Brexit period. ${ }^{138}$ Children in Northern Ireland should not be refused their Irish citizenship, which brings along the benefits of EU citizenship,

\footnotetext{
${ }^{130}$ Brexit and Children Coalition (n 16) 27.

131 ibid.

${ }^{132}$ Brexit and Children Coalition (n 16) 27.

133 ibid, 28.

134 Committee on the Rights of the Child (n 109) para 36.

135 Committee on the Rights of the Child (n 109).

136 ibid, para 46.

137 ibid, para 47.

${ }^{138}$ Brexit and Children Coalition (n 16) 28.
} 
despite the fact that the UK will leave the Union. Another element is related to maintaining the ability of children to access health, education and care services across the border. ${ }^{139}$

Finally, the best-interest principle can also guide the protection of children's interests in light of the uncertainties of the withdrawal negotiations and the possibility of a no-deal scenario ${ }^{140}$ if no agreement is concluded. The primary obligation of the state parties to consider the best interest implies that children's interests may not be weighted equally in the long line of other pressing issues. ${ }^{141}$ Children's interests need to be 'highlighted' in order not to be ignored. ${ }^{142}$ Hence, even if an overall agreement on the UK's leaving is not reached, children's rights should not simply be placed on the pile with all the other unresolved issues. A primary consideration for the best-interest principle can imply the conclusion of a separate agreement which is to deal solely with the consequences of the removal of the freedom of movement law and the maintenance of children's equilibrium before and after Brexit.

\subsection{Application of European law}

As demonstrated in the previous sub-part, by incorporating the children's equilibrium goal in their activities, the UK and EU authorities could safeguard and ameliorate transition to the post-Brexit period for children affected by the UK's withdrawal. Next, it can be useful to consider which approaches could be utilised in the interpretation of the post-Brexit EU law rights of children with UK citizenship, given that such children would not be able to be simply regarded as 'third-country nationals' after the withdrawal. In the background of the current legal uncertainties, which could even pile up after Brexit day, the reasonings of the Court which took into consideration the specific needs of children could serve as a smooth transition mechanism in the interpretation of the rights of children with UK citizenship living in the Union.

The progress of the Brexit debates suggests that equal treatment is to be applied in matters concerning education, including in relation to Regulation No 492/2011. ${ }^{143}$ As demonstrated in the part on children's ed-

\footnotetext{
139 ibid.

${ }^{140}$ As of 30 October 2018, the possibility of a no-deal scenario is still quite possible. See P Inman, ' No-deal Brexit Would Trigger Lengthy UK Recession, Warns S\&P' The Guardian (30 October 2018, London) <www.theguardian.com/business/2018/oct/30/no-deal-brexit-would-trigger-lengthy-uk-recession-warns-sp> accessed 30 October 2018.

141 Committee on the Rights of the Child (n 109) para 37.

142 ibid.

${ }^{143}$ European Commission (n 116) para 31.
} 
ucation rights, once acquired, the right to education bears independent status from the other requirements in the Regulation and could anchor the residence rights of the third-country national carer. Children with third-country nationality could also benefit from the right of access to education. As for the requirement of the parent (or carer) being a migrant worker within the meaning of the Regulation, the case law of the ECJ has demonstrated that in regard to Article 10, there is very broad understanding of the definition of 'migrant worker', including that of being a person who was neither living nor working in the host state at the time of the education of his (step-)children. Hence, the wide understanding of this right, grounded on a consideration of children's specific needs, can allow children with UK citizenship who have parents that have worked as EU citizens (inclusive of times prior to Brexit day) in one of the 27 Member States not only to continue their studies but also to anchor the residence and social assistance rights of their families, similarly to the case of Ibrahim.

The broad scope of the right to education in the post-Brexit phase could paradoxically serve to keep children with UK citizenship 'integrated' in the Union. To elaborate, due to its crucial importance, the ability of the child to become enrolled in the education system of the Member State naturally becomes a cornerstone in the process of integration. ${ }^{144}$ The securing of the right to education from any possible abruptions demands that it first and foremost needs to become independent from the integration process of the migrant worker. The specific development course of this right could therefore not only contribute to the children's education, but could support the preservation of children's rights under the Charter and thus be one of the bridges for safeguarding some of the child's best interests between the current state of EU law and post-Brexit EU legal developments.

Apart from education rights, the rights to freedom of movement were one of the main levers for greater European integration. The removal of EU citizenship status, resulting in the curtailing of the freedom of movement and residence, will be one of the considerable setbacks for UK nationals, living and/or working in one or several Member States. Ironically, the ones who would probably be mostly affected by the UK's withdrawal will be exactly those who decided to take advantage of their freedom of movement rights and settle in another EU Member State.

\footnotetext{
${ }^{144}$ In Maria Teixeira, Advocate General Kokott stated that the ancillary residence right of the primary carer is the best possible way for the integration of the children of migrant workers in the host Member State. See Case C-480/08 ECLI:EU:C:2009:642, Opinion of AG Kokott, para 62.
} 
The process of European integration has also shaped the lives of children with EU citizenship by enabling many of them to build up relations with various states. The preservation of the ties that a child has with different Member States resulted in judgments where, on the basis of European citizenship and the freedom of movement, the Court was able to rule even on sensitive domestic law topics, such as name formation. ${ }^{145}$ Furthermore, the Court has underlined in numerous cases that the right to free movement should not result in an unequal treatment of rights in the host state since this might dissuade citizens from exercising the rights to freedom of movement in the first place. ${ }^{146}$

On the basis of the latter, the post-Brexit EU law environment, even if resulting in the inapplicability of the status of EU citizenship for British nationals, should strive not to penalise those who have established their lives in the 27 Member States in line with the process of European integration. ${ }^{147}$ The legal instability of the situation requires a comprehensive approach, which could ameliorate the effects of the UK's withdrawal at least for children who will lose the status of EU citizenship. For this purpose, where the jurisdiction of EU law is applicable, recourse could be made to children's equilibrium which encompasses children's rights as enlisted in Article 24 of the Charter. In addition, attention should be paid to how this equilibrium is achieved and maintained. As the case law on children's freedom of movement has demonstrated, it is crucial that attention is paid to children's individual rights and interests. The assessment of the withdrawing of the freedom of movement rights against children's equilibrium can lead to the conclusion that some essential cross-Member State ties that the child has formed on the basis of the freedom of movement law should be preserved post-Brexit.

${ }_{145}$ Garcia Avello (n 9) and Case C-353/06 Grunkin-Paul ECLI:EU:C:2008:559.

146 This argument was used in numerous cases, such as in Case C-127/08 Blaise Baheten Metock and Others $v$ Minister for Justice, Equality and Law Reform ECLI:EU:C:2008:449, paras 63-64; Joined Cases C 523/11 and C-585/11 Laurence Prinz v Region Hannover and Philipp Seeberger $v$ Studentenwerk Heidelberg ECLI:EU:C:2013:524, para 32.

${ }^{147}$ As some campaigners have argued: 'If the fundamental status of EU citizenship means anything at all, we need to be protected rather than penalised for seizing all the opportunities that European citizenship has given us - and which were confirmed by successive UK governments during the UK's membership of the EU'. See 'Letter to UK and EU Negotiating Teams' British in Europe (2018) <https://britishineurope.org/letter-to-uk-eu-negotiating-teams/> accessed 19 October 2018. This point is particularly valid for children. As some studies suggest, they could be one of the significantly affected groups after the withdrawal, since the process of integration could have nurtured a feeling in them of being both European and British. See Coram (n 5) 7. 


\section{Conclusion}

The development of European law discourse has resulted in the gradual evolution of the consideration of children's specific needs. From extending the scope of the child's right to access education on the basis of Regulation No 492/2011, through consideration of the constitution of children's genuine enjoyment of the status of EU citizenship, the ECJ has aided the advancement of the idea that children's rights should be examined with reference to their fundamental rights status for children. This development, however, has not been smooth and linear, but rather sporadic or resulting, as a side effect, from the deliberation of the rights of the European migrant worker. In some instances, children's specific needs under European law were only a background to the discussion of the entitlements of their parents. Such reasoning resembles the approach of the 'will' theorists, arguing that only those with volitional capacities could take advantage of their rights. The flaw in this reasoning is that it omits the presence of the children's own rights, which require examination on the basis of the children's interests.

Consideration of children's own rights is crucial, especially in instances where the existing social arrangements are, or would be, shaken and even terminated. Brexit is an example in this regard in terms of an event which could result in numerous legal challenges for people with British citizenship who have utilised their freedom of movement rights, as well as EU citizens residing in the UK. This is even more valid for children affected by Brexit who are growing up within the process of European integration.

Any potential amelioration of the results related to the UK's withdrawal can draw inspiration from the concept of children's equilibrium, developed by the Court, by also minding the lessons derived from the omissions of the ECJ in the consideration of children's rights. One such omission concerned the Court's ambivalent recognition of children as autonomous rights bearers that have specific and individual needs, which is a precondition for the achievement of children's equilibrium.

Given that the constitution of children's equilibrium, as defined by the Court, encompasses some of the most prominent rights of the CRC, the concept could guide the assessment of children's rights after Brexit day. The utilisation of the child-specific approach towards the goal of children's equilibrium will also enable smoother transition in the wake of the inapplicability of the freedom of movement law. In view of the upcoming legal turbulences, the inclusion of children's equilibrium as an objective in the Withdrawal Agreement, alongside the child-related approach, will be in line with and in implementation of the obligations of both the UK and the Member States under the CRC. 
There should be a parallel commitment from both the EU and the UK on the preservation of children's interests, which is to stand regardless of how the Brexit negotiations unfold and whether an agreement will be reached. The adoption of the children-related approach can be a constant contributing to the preservation of 'children's equilibrium' in the wake of the costs of the UK's withdrawal from the EU. The future lies in the hands of the children; ${ }^{148}$ hence the responsibility of achieving a 'comprehensive and robust protection for the rights of children' should be of paramount importance in the ongoing negotiations.

$\overline{148}$ Brexit and Children Coalition (n 16) 35. 